\title{
Hosszú távú progressziómentes túlélés relabált, refrakter myeloma multiplex tisztán orális ixazomib-lenalidomid-dexametazon kezelésével
}

\author{
Hardi Apor dr. ${ }^{1}$ - Varga Gergely dr. ${ }^{2}$ - Nagy Zsolt dr. ${ }^{3}$ \\ Kosztolányi Szabolcs dr. ${ }^{4}$ - Váróczy László dr. ${ }^{5}$ - Plander Márk dr. ${ }^{6}$ \\ Schneider Tamás dr. ${ }^{7}$ - Demeter Judit dr. ${ }^{3}$ - Alizadeh Hussain dr. ${ }^{4}$ \\ Illés Árpád dr. ${ }^{5}$ - Masszi Tamás $d r^{2}{ }^{2}$ Mikala Gábor dr. ${ }^{1}$ \\ ${ }^{1}$ Dél-pesti Centrumkórház, Országos Hematológiai és Infektológiai Intézet, \\ Hematológiai és Őssejt-transzplantációs Osztály, Budapest \\ ${ }^{2}$ Semmelweis Egyetem, Általános Orvostudományi Kar, Belgyógyászati és Hematológiai Klinika, Budapest \\ ${ }^{3}$ Semmelweis Egyetem, Általános Orvostudományi Kar, Belgyógyászati és Onkológiai Klinika, Budapest \\ ${ }^{4}$ Pécsi Tudományegyetem, Általános Orvostudományi Kar, I. Belgyógyászati Klinika, Pécs \\ ${ }^{5}$ Debreceni Egyetem, Általános Orvostudományi Kar, Belgyógyászati Intézet, Hematológiai Klinika, Debrecen \\ ${ }^{6}$ Markusovszky Egyetemi Oktatókórház, Szombathely \\ ${ }^{7}$ Országos Onkológiai Intézet, Hematológiai Osztály, Budapest
}

Bevezetés: A myeloma multiplex mindmáig alapvetően gyógyíthatatlan betegség, ezért nagy klinikai jelentőségük van az eredményes mentő kezeléseknek. A szájon át adható első proteaszómagátlóval, az ixazomibbal kiegészített lenalidomid-dexametazon terápia jól tolerálható, csak orális szerekből álló kombináció, mely hazánkban 2015 áprilisától kezdődően a „Named Patient Program” keretén belül vált elérhetővé relabált, refrakter myeloma multiplexes betegek kezelésére.

Célkitüzés: Kutatásunk célja az ixazomib-lenalidomid-dexametazon kezelés mellett a hosszú távon progressziómentes túlélők célzott vizsgálata.

Módszer: A program keretében összesen 7 centrumban 80 visszaeső beteg részesült e triplet kezelésben, adataikat retrospektíven elemeztük. Leíró statisztikai és Kaplan-Meier-analízist végeztünk.

Eredmények: A betegek nagyobb hányada reagált: 63,75\%-os válaszarány mellett 14 (17,5\%) betegnél nem volt terápiás válasz/stabil betegség alakult ki, és 15-nél (18,75\%) a betegség a kezelés mellett is progrediált. A progressziómentes túlélés a teljes betegcsoportban 10,6 hónapnak adódott, ugyanakkor 16 beteg (18,75\%) két éven túl progressziómentesnek bizonyult, sốt közülük 11-nél a betegség még 3 év után sem progrediált. Tanulmányunkban a fenti, hosszú távú túlélő betegcsoport tulajdonságait tárjuk fel.

Megbeszélés: A folyamatos terápia a myeloma multiplex kezelésében meghatározóvá vált. Ezért fontos ismernünk, hogy kik lehetnek azok a betegek, akik különösen sokat profitálnak egy bizonyos terápiából. A hosszú távon progressziómentes túlélők között az immunglobulin-nehézláncot érintő transzlokációk vagy triszómiák közül (trend szintjén) az utóbbiak kedvezőbb progressziómentes túléléssel bírtak, de progressziómentes platót mindkét betegcsoportban észleltünk. A betegség tumortömegét mérő nemzetközi stádiumbeosztás (ISS) nem jelezte előre a hosszú túlélést. Gyógyszerelhagyáshoz vezető mellékhatást a hosszú távú túlélő csoportban egyet sem regisztráltunk; az észlelt mellékhatások nagy része enyhe volt.

Következtetések: Munkánk során az ixazomib-lenalidomid-dexametazon kombinációt effektívnek és biztonságosnak találtuk relabált, refrakter myeloma multiplex kezelésére, mely a betegek mintegy hatodánál több éven át eredményesen alkalmazható. Cikkünkkel a hazai beteganyagon szerzett tapasztalatainkat szeretnénk megosztani a COVID-19világjárvány alatt különösen aktuálissá vált, tisztán orális terápiás lehetőségről.

Orv Hetil. 2021; 162(36): 1451-1458.

Kulcsszavak: myeloma multiplex, ixazomib, lenalidomid 


\title{
Long-time progression-free survival in relapsed, refractory multiple myeloma with the oral ixazomib-lenalidomide-dexamethasone regime
}

\begin{abstract}
Introduction: Despite great advances in therapy, multiple myeloma is still a largely incurable disease, therefore the importance of salvage therapies is paramount. The first oral proteasome inhibitor ixazomib in combination with lenalidomide-dexamethasone is a tolerable, orally administered regime, which has become available for Hungarian relapsed, refractory multiple myeloma patients from April 2015 in the Named Patient Program.

Objective: Our goal was to investigate the long-time progression-free surviving patient population treated with the ixazomib-lenalidomide-dexamethasone triplet.

Method: We retrospectively studied a total of 80 patients from 7 centers who received the triplet combination. Survival analyses were performed.

Results: Two-third of the patients responded: the overall response rate was $63.75 \% .14$ patients (17.5\%) did not respond/had stable disease and 15 patients (18.75\%) outright progressed upon therapy. Although progression-free survival was only 10.6 months for the entire patient cohort, the disease in a subgroup of 16 patients did not progress within two years. In fact, 11 of them were still in sustained remission after 3 years of therapy. Our goal was to analyze the characteristics of this subgroup.

Discussion: The idea of long-term therapy of multiple myeloma is gaining widespread acceptance. Therefore it is important to know which patients may benefit the most from certain therapies. Among these 16 long-term responder patients, reciprocal translocation of the immunoglobulin heavy chain seemed to lack an adverse impact on progression-free survival; comparable to trisomies, both curves had a progression-free plateau. The International Staging System (ISS) score at the start of therapy did not predict long-term survivorship. Most of the side effects in this subgroup were mild, manageable, none led to therapy discontinuation.

Conclusion: Ixazomib-lenalidomide-dexamethasone was confirmed to be an effective and safe combination for relapsed, refractory multiple myeloma, and one-sixth of the treated patients were able to receive it for several years, effectively. This fully oral therapeutic option is at its best during the present COVID-19 pandemic.
\end{abstract}

Keywords: multiple myeloma, ixazomib, lenalidomide

Hardi A, Varga G, Nagy Zs, Kosztolányi Sz, Váróczy L, Plander M, Schneider T, Demeter J, Alizadeh H, Illés Á, Masszi T, Mikala G. [Long-time progression-free survival in relapsed, refractory multiple myeloma with the oral ixazomib-lenalidomide-dexamethasone regime]. Orv Hetil. 2021; 162(36): 1451-1458.

(Beérkezett: 2021. január 17.; elfogadva: 2021. március 6.)

\begin{abstract}
Rövidítések
ASCT $=$ (autologous stem cell transplantation) autológcsontvelö-transzplantáció; COVID-19 = (coronavirus disease 2019) koronavírus-betegség 2019; CR = (complete response) teljes válasz; EMA = (European Medicines Agency $)$ Európai Gyógyszerügynökség; FDA = (U. S. Food and Drug Administration) az Amerikai Egyesült Államok Élelmiszer-biztonsági és Gyógyszerészeti Hivatala; FISH = fluoreszcens in situ hibridizáció; $\mathrm{IgG}=$ immunglobulin- $\mathrm{G} ; \operatorname{IgH}=$ (immunoglobulin heavy chain) immunglobulin-nehézlánc; IMWG = (International Myeloma Working Group) Nemzetközi Myeloma Munkacsoport; IRd = ixazomib-lenalidomid-dexametazon; ISS $=($ International Staging System) nemzetközi stádiumbeosztás; ORR = (objective response rate) teljes válaszarány; $\mathrm{PR}=$ (partial response) részleges válasz; $\mathrm{Rd}=$ lenalidomid-dexametazon; UVEA-IXA = Use Via Early Access to Ixazomib
\end{abstract}

A myeloma multiplex a második leggyakoribb hematológiai malignoma, egyben a leggyakoribb csontvelői kiindulású rosszindulatú megbetegedés [1]. Bár az elmúlt két évtized jelentős fejlődést hozott a betegség kezelési eredményességének terén, ám a myeloma mind ez idáig alapvetően gyógyíthatatlannak bizonyult. A betegség kórlefolyását remissziók és visszaesések egymásutánja jel- lemzi, ez pedig felértékeli a hatékony mentő kezelések jelentőségét.

Az immáron lassan két évtizede rendelkezésre álló első proteaszómagátló, a bortezomib mellett jelenleg két második generációs gyógyszer (a karfilzomib és az ixazomib) is tagja a myeloma multiplex terápiáját forradalmasító farmakológiai csoportnak. Az első orális proteaszómagátló, az ixazomib az FDA és az EMA törzskönyvezési vizsgálatát követően lenalidomiddal és dexametazonnal kombinációban relabált, refrakter myeloma multiplex kezelésére szerzett javallatot 2015ben [2]. Ezt követően a fenti kombináció 2015 decemberétól 2017 áprilisáig a hazai gyakorlatban elérhető volt a Takeda vállalat (Tokió, Japán) jóvoltából létrehozott „Named Patient Program” keretén belül olyan, visszaeső és/vagy terápiarefrakter myeloma multiplex betegségben szenvedők számára, akik legalább egy kezelési vonalban részesültek, majd betegségük progrediált, és új kezelésre szorultak. A terápiás eredmények értékeléséról konzorciumunk az első hazai multicentrikus myeloma multiplex kezelési tanulmányban korábban már beszámolt: a 77 beteget számláló vizsgálati csoport progreszsziómentes túlélése 11,4 hónapnak adódott 12,5 hónap medián követési idő mellett, ezen belül a korábban egy 
kezelési vonalban kezelt betegek trend szintjén hosszabb progressziómentességet mutattak [3]. Magas rizikójú és standard rizikójú betegek esetén is egyformán hatékonynak találtuk a kezelést. A kezelés során öt halálos kimenetelü szövődmény lépett fel: három infekció és kettő pulmonalis embolia. Gyógyszerelhagyáshoz vezető mellékhatást nem regisztráltunk. Jelen közleményünkben medián négyéves követés mellett elemezzük a fenti protokollal elért terápiás eredményeket, különös figyelemmel a hosszú remissziót mutató betegcsoportra.

\section{Módszerek}

Retrospektív kutatásunk célja az ixazomib-lenalidomiddexametazon (IRd-) kezelés hatásosságának és biztonságosságának vizsgálata a magyar gyakorlatban, különös tekintettel egy, a kezelésben hosszan és eredményesen részesülő betegcsoportra. A tanulmány beválasztási kritériumait az 1 . táblázat tartalmazza. A kezelés 28 napos ciklusokból állt: az 1-21. napig 25 mg kezdő dózisú lenalidomidtabletta, az 1., 8., 15. és 22 . napon $40 \mathrm{mg}$ dexametazontabletta és az 1., 8. és 15 . napon 4 mg kezdó dózisú ixazomibtabletta. Dózisredukcióra hematológiai toxicitás vagy beszúkült vesefunkciók miatt kerülhetett sor. A kezelés a progresszióig, intoleranciáig vagy a beteg haláláig folyhatott. Elemeztük, hogy van-e különbség az általunk vizsgált tulajdonságokban a kezelés mellett hosszan túlélő betegek és azon páciensek között, akiknek a betegsége korán progrediált. Célkeresztünkben a betegségjellemzők, úgymint a nemzetközi stádiumbeosztás (International Staging System, ISS), a fluoreszcens in situ hibridizációs (FISH-) technikával meghatározott citogenetikai háttér, a klinikum mint terápiás válasz, a

1. táblázat |Az ixazomib személyre szóló beválasztási kritériumai

\footnotetext{
Életkor $\geq 18$ év

Standard kritériumok alapján diagnosztizált myeloma multiplex

Minimum 1, maximum 3 megelőző terápiás vonal

Jelenleg nem kezelt (kivéve szteroid), biokémiai vagy tünetes relapsus a jelentkezés idején

A következő terápiás terv ixazomib-lenalidomid-dexametazon

Lenalidomidra vagy proteaszómagátlóra érzékeny beteg, vagy korábban nem bizonyult ezekre refrakternek

Neutrophil granulocyták száma $\geq 1000 / \mu l$ és thrombocytaszám $\geq 75000 / \mathrm{ul}$

Szérum-összbilirubin < a normálérték felső határának másfélszerese

ASAT /ALAT < a normálérték felső határának háromszorosa

Számított kreatinin-clearance $\geq 30 \mathrm{ml} / \mathrm{min}$

ECOG-pontszám $=0 / 1 / 2$
}

A beteg beleegyezik a kezelés során, illetve utána 90 napig tartó hatásos terhességmegelőzésbe

ALAT $=$ alanin-aminotranszferáz; ASAT $=$ aszpartát-aminotranszferáz; ECOG $=$ Keleti Kooperatív Onkológiai Csoport progressziómentes túlélés és a mellékhatások egyaránt szerepeltek. Munkánkhoz a kezelőorvosok által rendelkezésünkre bocsátott klinikai adatokat használtuk. Öszszehasonlító elemzésünkből kizártuk azokat a betegeket, akik egy kezelési ciklust sem teljesítettek. A legtöbb részt vevő intézményben a citogenetikai vizsgálat megelőző plazmasejt-szelekció nélkül történt, illetve nem egységes FISH-próba-panelt alkalmaztak, azonban a $-17 \mathrm{p}-\mathrm{t}$, t(11;14)-t, t(4;14)-t, t(14;16)-ot és lq21 amplifikációkat minden teszt tartalmazta. Sajnos 21 esetben $(26,25 \%)$ nem állt rendelkezésre diagnóziskori FISH-eredmény, ebből 4 érintett hosszú távú túlélő beteg volt. Az IRdterápiát közvetlenül megelőző citogenetikai adatok esetében még kevesebb adat érkezett, 50 esetben (62,5\%) nem állt rendelkezésre friss FISH-eredmény, ez a hosszú távú túlélők felét érintette (8 eset). A terápiás választ a Nemzetközi Myeloma Munkacsoport (International Myeloma Working Group, IMWG) által meghatározott kritériumok szerint értékeltük [4]. Az IMWG kritériumrendszere szerint meghatározott progresszió, halál vagy dokumentált progresszió nélkül új terápiás vonal megkezdése esetén progrediált betegséggel élő páciensként azonosítottuk a beteget. Statisztikai elemzésünket a GraphPad Prism szoftverrel készítettük el (8.4.3. verzió; GraphPad Software, San Diego, CA, Amerikai Egyesült Államok), statisztikai analíziseinket Mantel-Cox-teszttel végeztük. A kezelésből hosszú távon profitáló betegeket mint hosszú távú túlélőket progressziómentes túlélésük alapján csoportosítottuk, beválasztási határértéknek két évet vettünk. Ez alapján 16 hosszan túlélő beteget azonosítottunk, akiknél az esetükben 53 hónapos követési idő alatt a progressziómentes túlélés görbéje még nem érte el a mediánt $(\mathrm{p}<0,0001)$, sugallva, hogy van egy olyan visszaeső és/vagy refrakter myeloma multiplex populáció, amelynek tagjai kifejezetten jól járnak az IRdkezeléssel. A kezelésbe, majd az elemző tanulmányba történő bevonást minden egyes beteg esetében az Országos Gyógyszerészeti és Élelmezési Intézet egyedi betegspecifikus engedélye biztosította.

\section{Betegek és betegségük jellemzői}

Tanulmányunkba 7 magyar centrumból 80 beteget válogattunk be; legfontosabb epidemiológiai adataikat a 2. táblázat tartalmazza, betegségük jellemzőit pedig a 3. táblázat. Ugyan nemzetközi szempontból viszonylag kicsi, de egységesen kezelt hazai betegszámról beszélünk. A medián életkor az IRd-kezelés kezdésekor a hosszú távú túlélők esetén másfél évvel magasabb volt, mint azoké, akiknek a betegsége korán progrediált $(63,4$ év vs. 61,8 év), illetve ebben a csoportban kétszer annyi volt a férfi, mint a nő (10/5 vs. 34/31). A diagnózistól az IRd-kezelés megkezdéséig eltelt idő mintegy három év volt mindkét csoportban, trend szintjén jelzetten hosszabb a hosszú távú túlélők javára (33 hónap vs. 36 hónap). A betegségre jellemző M-protein jellege azonos mértékben oszlott meg a két populáció között. A diag- 
2. táblázat |A tanulmányban részt vevő betegek kiemelt jellemzői

\begin{tabular}{|c|c|c|c|}
\hline & Összes beteg & $\begin{array}{l}\text { Hosszú } \\
\text { távú } \\
\text { túlélók }\end{array}$ & $\begin{array}{c}\text { Rövid távú } \\
\text { túlélők }\end{array}$ \\
\hline Betegszám & 80 & 15 & 65 \\
\hline Férfi & 44 & 10 & 34 \\
\hline Nő & 36 & 5 & 31 \\
\hline $\begin{array}{l}\text { Diagnóziskori medián } \\
\text { életkor (év) }\end{array}$ & 62,3 & 63,4 & 61,1 \\
\hline $\begin{array}{l}\text { Ixazomib kezdésekor } \\
\text { medián életkor (év) }\end{array}$ & 66,8 & 68,2 & 66,8 \\
\hline $\begin{array}{l}\text { A diagnózistól az ixazomi- } \\
\text { big eltelt medián idő (hó) }\end{array}$ & 36,0 & 33,0 & 36,1 \\
\hline Korábbi V/T/R kezelés & $77 / 69 / 18$ & $14 / 14 / 4$ & $63 / 55 / 14$ \\
\hline $\begin{array}{l}\text { Korábbi kezelési vonalak } \\
\text { mediánja }\end{array}$ & 2 & 2 & 2 \\
\hline Megelőző ASCT & 39 & 8 & 31 \\
\hline ORR & 0,64 & 0,93 & 0,57 \\
\hline $\begin{array}{l}\mathrm{CR} / \mathrm{VGPR} / \mathrm{PR} / \text { nem } \\
\text { ismert válasz }\end{array}$ & $7 / 10 / 34 / 7$ & $2 / 5 / 7 / 1$ & $5 / 5 / 27 / 6$ \\
\hline $\begin{array}{l}\text { IgH-transzlokáció, } \\
\text { medián OS (hó) }\end{array}$ & 45,3 & 74,8 & 37,1 \\
\hline $\begin{array}{l}\text { IgH-transzlokáció, } \\
\text { medián PFS (hó) }\end{array}$ & 8,3 & 41,9 & 5,4 \\
\hline Triszómia medián, OS (hó) & 75,6 & 81,1 & 67,0 \\
\hline Triszómia medián, PFS (hó) & 8,3 & 48,1 & 6,7 \\
\hline $\begin{array}{l}\text { IgH/triszómia nélkül, } \\
\text { medián OS (hó) }\end{array}$ & 62,4 & 79,7 & 51,4 \\
\hline $\begin{array}{l}\text { IgH/triszómia nélkül, } \\
\text { medián PFS (hó) }\end{array}$ & 3,9 & 35,8 & 3,4 \\
\hline
\end{tabular}

ASCT = autológcsontvelő-transzplantáció; $\mathrm{CR}=$ teljes válasz; $\mathrm{IgH}=$ immunglobulin-nehézlánc; ORR = teljes válaszarány; OS = teljes túlélés; PFS = progressziómentes túlélés; $\mathrm{PR}=$ részleges válasz; $\mathrm{V} / \mathrm{T} / \mathrm{R}=$ bortezomib/thalidomid/lenalidomid; VGPR = nagyon jó részleges válasz

nóziskori eredményeket tekintve a hosszú távú túlélők között egyetlen, nagy rizikójúnak minősített citogenetikai eltéréssel rendelkező beteg sem szerepelt, míg a kezelés előtti FISH alapján 1 betegnél adódott $-17 \mathrm{p}$ (-p53) eltérés. Az ISS-pontszám megoszlása a hosszan túlélők esetén nem különbözött azon társaikétól, akiknek a betegsége rövid távon progrediált. 3 beteget leszámítva minden résztvevő kapott már valamilyen, proteaszómagátlót és immunmodulátort (IMID) tartalmazó kezelést; 63 beteg thalidomid-, 18 beteg lenalidomid-, 77 beteg bortezomib-, 3 beteg karfilzomibkezelésben korábban már részesült. Azon páciensek 70,7\%-a, akiknek a betegsége korán progrediált (13/64), míg a hoszszú távú túlélők 59,8\%-a (5/16) volt lenalidomidnaiv a kezelés megkezdésekor. A betegek fele mindkét csoportban átesett már autológőssejt-transzplantáción (ASCT). A hosszú távon túlélő betegek kevesebb megelőző kezelési modalitásban részesültek: 46,7\%-uk (7 eset) második kezelési vonalként, 26,7\%-uk (4-4 eset) harmadik vagy
3. táblázat A myeloma multiplex betegség jellemzői a diagnóziskor

\begin{tabular}{lccc}
\hline & Összes beteg & $\begin{array}{c}\text { Hosszú } \\
\text { távú túlélők }\end{array}$ & $\begin{array}{c}\text { Rövid távú } \\
\text { túlélők }\end{array}$ \\
\hline $\begin{array}{l}\text { IgG-termelő myeloma } \\
\text { multiplex }\end{array}$ & 48 & 10 & 39 \\
$\begin{array}{l}\text { IgA-termelö myeloma } \\
\text { multiplex }\end{array}$ & 10 & 1 & 9 \\
$\begin{array}{l}\text { IgD-termelő myeloma } \\
\text { multiplex }\end{array}$ & 1 & 0 & 1 \\
$\begin{array}{l}\text { IgE-termelö myeloma } \\
\text { multiplex }\end{array}$ & 1 & 1 & 0 \\
$\begin{array}{l}\text { IgM-termelő } \\
\text { myeloma multiplex }\end{array}$ & 1 & 0 & 1 \\
$\begin{array}{l}\text { Kappa-könnyúlánc } \\
\text { Lambda-könnyúlánc }\end{array}$ & 55 & 11 & 44 \\
Csak könnyú láncot & 19 & 4 & 21 \\
\hline
\end{tabular}

termelő myeloma

multiplex

Nonszekretoros

myeloma multiplex

Diagnóziskori ISS

$1 / 2 / 3 /$ nem ismert

IRd kezdésekori ISS $\quad 28 / 11 / 18 / 23 \quad 7 / 2 / 4 / 3 \quad 21 / 9 / 14 / 20$

$1 / 2 / 3 /$ nem ismert

Nagy rizikójú FISH

$25 / 17 / 28 / 10 \quad 4 / 2 / 6 / 3 \quad 21 / 15 / 22 / 7$

0

7

FISH = fluoreszcens in situ hibridizáció; Ig = immunglobulin; IRd = ixazomib-lenalidomid-dexametazon; ISS = nemzetközi stádiumbeosztás

ennél későbbi terápiaként kapta a vizsgálati protokollt. A tanulmány ideje alatt a lenalidomidot egyedi méltányossági kérelemhez és annak háromhavonta történő ismételt igényléséhez kötötték a finanszírozási szabályok, és ennek pozitív elbírálása - fooleg a szóban forgó időszak elején - legalább két megelőző vonalat feltételezett, ez magyarázza a több vonalban előkezelt betegek viszonylag magas arányát. Esetenként a kérvény elmaradása kényszerü - adminisztratív okú - terápiamegszakításhoz vezetett.

\section{Eredmények}

\section{Hatékonyság}

A tanulmányban részt vevő 80 beteg közel kétharmada kedvező terápiás válasszal reagált a kezelésre, a teljes válaszarány (ORR) 63,75\%-nak adódott. Míg 15 esetben $(18,75 \%)$ a kezelés ellenére progresszió alakult ki, 16 beteg hosszú távon profitált belőle. A hosszú távú túlélők nem szignifikánsan ugyan, de értelemszerűen jobb terápiás választ értek el, mint a teljes betegcsoport: 2 teljes válasz (CR) (13,33\%), 5 nagyon jó részleges válasz ([5]) (33,33\%), 7 részleges válasz $(P R)(46,67 \%)$ alakult ki, 1 esetben nem ismert a legjobb elért válasz. Azon alcsoport esetén, amelyben a betegség 2 éven belül progredi- 
ált, teljes válasz és nagyon jó részleges válasz 5-5 (7,69\%), míg részleges válasz $27(41,6 \%)$ esetben alakult ki. Itt sem volt ismert az elért legjobb terápiás válasz $6(9,23 \%)$ esetben. 53 hónap medián követés után 11 beteg $(13,75 \%)$ jelenleg is IRd-kezelés alatt áll, illetve a hosszú távon túlélők progressziómentes túlélésének görbéje még nem érte el a mediánt. Vizsgáltuk a progressziómentes túlélés alakulását az ixazomibkezelés megkezdése előtti ISS szerint (1. ábra), illetve a terápiás válasz szintjéhez rendelve (2. ábra), immunglobulin-nehézlánc ( $\mathrm{IgH})$ transzlokációja és triszómiák jelenléte (valószínú hyperdiploiditas) szerint bontva (3. ábra), valamint a megelőző terápiák számának függvényében (4.ábra). 23 esetben sajnos nem állt rendelkezésre a kezelés megkezdése előtti ISS-érték. A hosszú távú túlélők kis száma miatt érdemi statisztikai összehasonlításra ilyen tekintet-

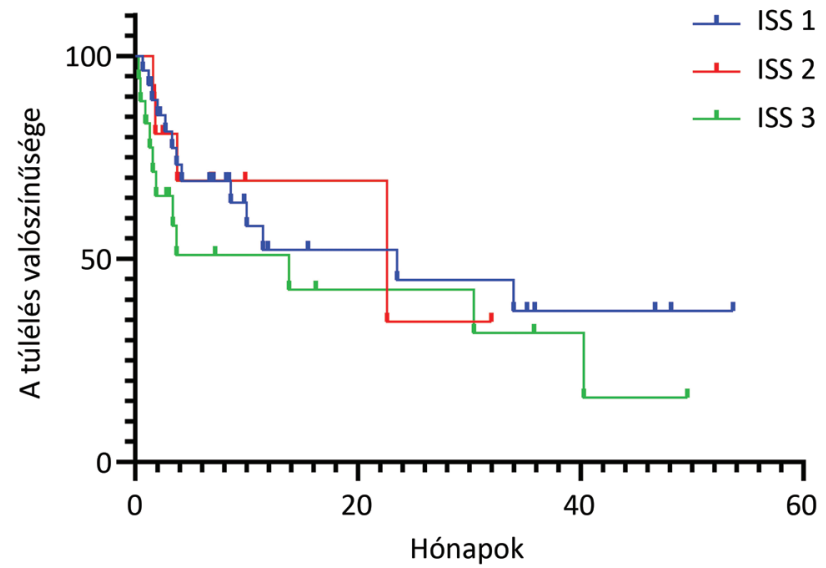

\begin{tabular}{l|l} 
1. ábra & A progressziómentes túlélés alakulása az IRd-kezelés megkez-
\end{tabular} dése előtti ISS szerint

IRd = ixazomib-lenalidomid-dexametazon; ISS = nemzetköz stádiumbeosztás

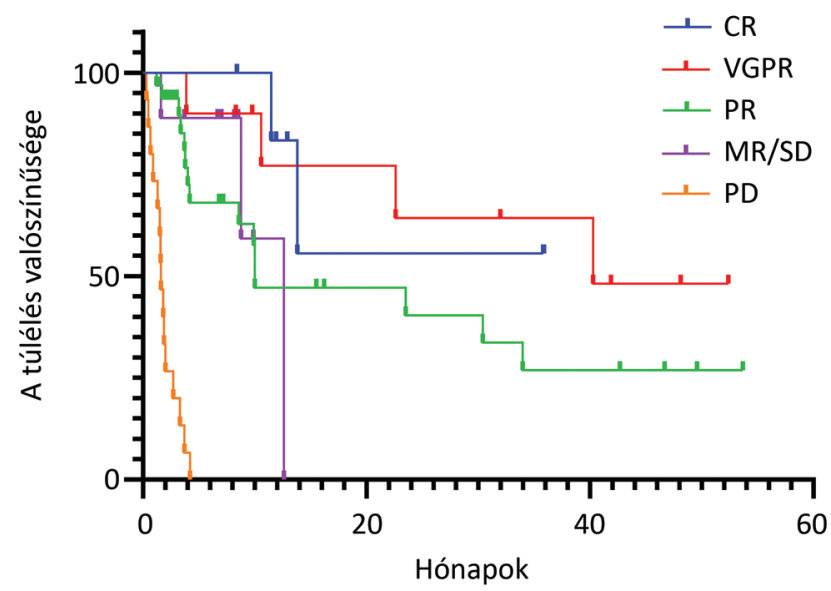

2. ábra

A progressziómentes túlélés alakulása a kezelésre adott legjobb válasz függvényében

$\mathrm{CR}=$ komplett remisszió; $\mathrm{PD}=$ progresszív betegség; $\mathrm{PR}=$ részleges válasz; $\mathrm{MR} / \mathrm{SD}=$ minimális válasz/stabil betegség; VGPR = nagyon jó részleges válasz ben nem volt lehetôségünk, érdemes azonban kiemelni, hogy míg közülük majdnem minden második beteg második terápiás vonalban részesült IRd-kezelésben $(46,7 \%)$, addig ugyanez csak szinte minden negyedik esetben volt igaz a maradék 65 beteg esetében $(27,5 \%)$.

\section{Mellékhatások}

48 kezelt beteg esetében (60\%) kezelőorvosaik nem jelentettek érdemi mellékhatást, a súlyos mellékhatások ritkák voltak (4. táblázat). A leggyakoribb mellékhatások vérképző szervi toxicitások voltak. A hosszan túlélők esetén szinte kizárólag csak hematológiai mellékhatást jelentettek, míg az összes beteg esetén 2 fatális pulmonalis emboliáról és 3, halálos kimenetű infekcióról számoltak be a kollégák (1 neutropeniás sepsis, 2 tüdőgyulladás). Halálos kimenetelű mellékhatás az általunk vizsgált alcsoportban nem volt. Dóziscsökkentésre pusztán 4 betegnél volt szükség, közülük 1 volt hosszú távú túlélő: a lenalidomid dózisát $25 \mathrm{mg}$-ról $10 \mathrm{mg}$-ra, az ixazomib dózisát 4 mg-ról 3 mg-ra csökkentette kezelőorvosa.

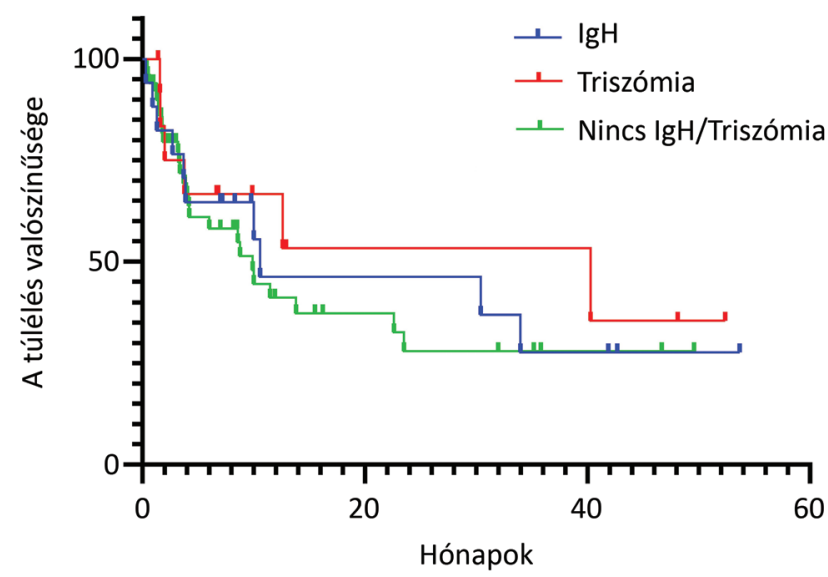

3. ábra $\mid$ A progressziómentes túlélés alakulása a diagnóziskori citogenetika alapján

IgH = immunglobulin-nehézlánc

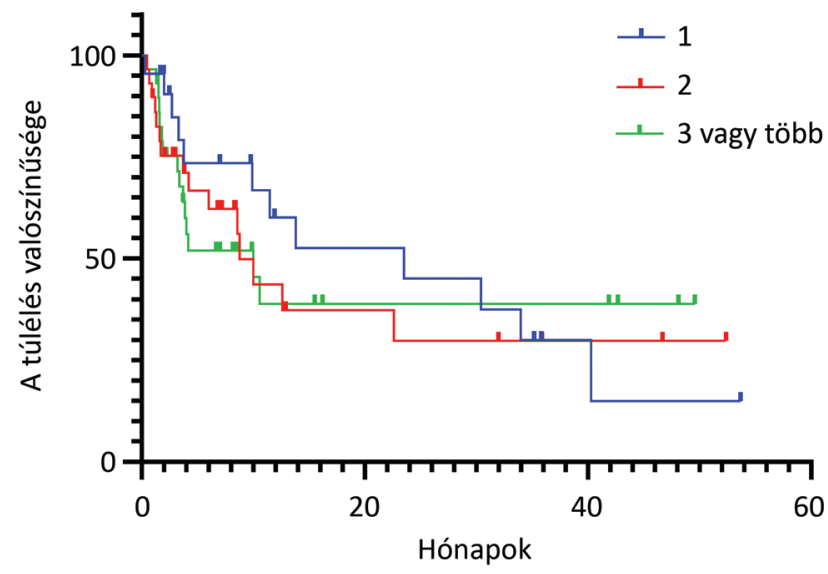

4. ábra $\mid$ A progressziómentes túlélés alakulása az IRd előtti kezelési vo nalak számának függvényében 
4. táblázat | Mellékhatások IRd-kezelés alatt (grade 3-4.)

\begin{tabular}{lccc}
\hline & $\begin{array}{c}\text { Összes } \\
\text { beteg }\end{array}$ & $\begin{array}{c}\text { Hosszú távú } \\
\text { túlélők }\end{array}$ & $\begin{array}{c}\text { Rövid távú } \\
\text { túlélők }\end{array}$ \\
\hline $\begin{array}{l}\text { Érdemi mellékhatás nélküli } \\
\text { terápia }\end{array}$ & 48 & 10 & 38 \\
$\begin{array}{l}\text { Cytopenia } \\
\text { Hasmenés }\end{array}$ & 19 & 4 & 15 \\
Infekció & 5 & 1 & 4 \\
Vascularis esemény & 6 & 0 & 6 \\
\hline
\end{tabular}

IRd = ixazomib-lenalidomid-dexametazon

\section{Megbeszélés}

A myeloma multiplex rendkívül heterogén biológiai hátterú betegség: betegeink mintegy fele hyperdiploid karakterü (triszómiákat hordoz), míg másik felük $\mathrm{IgH}-\mathrm{t}$ érintő transzlokációt hordoz [6]. Bármely kezelési protokoll alkalmazásakor szükségszerúen vannak alul- és túlkezelt betegeink. Saját kezelési eredményeink utólagos értékelése fogódzót nyújthat a késóbbi jó terápiás választáshoz, annak jobb „személyre szabottságához”.

Myelomás betegeink IRd-kezelésére az első hazai, multicentrikus, myeloma multiplex terápiát célzó "Named Patient Program" keretében kerülhetett sor. Kezelt betegeink között négy évet meghaladó medián követés mellett 16 olyan személyt azonosítottunk, akinél a myeloma progressziója 2 évnél még nem lépett fel, míg a teljes betegcsoportban a medián progressziómentesség 10,6 hónap volt. Ezen túlmenően, 36 hónap követés után 11 betegnél egyáltalán nem észleltünk progressziót. Hosszú távú túlélőink között reciprok IgH-transzlokáció 5 esetben $(33,3 \%)$, triszómia 3 esetben (20\%) igazolódott a diagnóziskori FISH-vizsgálattal, míg ugyanez az arány azok csoportjában, akiknek a betegsége két évnél korábban progrediált, 12 (18,5\%) és 11 (16,9\%) volt. Ez alapján vizsgálva az összes beteget, triszómiák jelenléte esetén 40,3 hónapos medián progressziómentes túlélést kaptunk, ami igen jó eredménynek tekinthető. IgH-t érintő transzlokációk esetén viszont csak 10,6 hónapot mértünk (Mantel-Cox-teszt, $\mathrm{p}=0,71$ ) (3. ábra). Ismert, hogy a reciprok IgH-transzlokációt hordozó, nem hyperdiploid betegek általában kedvezőtlenebb prognózisúak, esetükben a proteaszómagátlót tartalmazó kombinációk előnyösebbek lehetnek [7]. A 3. ábrán látszik, hogy bár a triszómiát hordozó (valószínúleg hyperdiploid) betegek túlélési görbéje magasabban fut, megfigyelhető egy másik hosszú, csaknem azonosan magasan futó, de kisebb betegszámú „plató” az IgH-transzlokációra pozitív, de mégis hosszan reagáló betegeket reprezentálva. A kedvezően reagáló betegek között szereplő IgHtranszlokáltak is szerepet játszhattak abban, hogy tanulmányunkban viszonylag magas a hosszú távú túlélők aránya.
Az IRd-kezelés megkezdése előtti stádium (ISS) megoszlása nem különbözött jelentősen a két csoport között. Az összes beteget vizsgálva, a kezelés előtti tumortömegnek nem volt szignifikáns hatása ugyan a kimenetelre, ISS szerinti 3 pont esetén azonban a legtöbb páciens betegsége alig egy év után progrediált: a medián progressziómentes túlélés $23,5,22,6$ és 13,8 hónapnak adódott ISS szerinti 1, 2 és 3 pont esetén (Mantel-Cox-teszt, $\mathrm{p}=0,47$ ) (1. ábra). Míg teljes válasz elérése esetén a túlélési görbe még nem érte el a medián értéket, illetve nagyon jó részleges válasz esetén 40,3 hónapos medián progressziómentességet kaptunk, addig részleges válasz, minimális válasz/stabil betegség és progresszív betegség esetén a medián progressziómentes túlélés lényegesen rövidebbnek, 10,3, 12,6, illetve 1,6 hónapnak bizonyult (Mantel-Cox teszt, $\mathrm{p}<0,0001$ ) (2. ábra). Azon páciensek betegsége, akik csak 1 korábbi kezelési vonalban részesültek, trend szintjén később progrediált, szignifikáns értéket azonban a korábbi terápiás vonalak számának függvényében sem kaptunk (MantelCox-teszt, $\mathrm{p}=0,83$ ) (4. ábra). Az összes betegre vonatkoztatva egy megelőző kezelés esetén a medián progressziómentes túlélés 23,5 hónap volt, míg két terápiás vonal után 8,8 hónapot, három vagy több megelőző kezelés után 10 hónapot kaptunk eredményül. Az IRd-kezelésből hosszú távon profitálók között minden második beteg korábban részesülhetett a fenti triplet kezelésből, mint társaik, ami hozzájárulhatott a hosszú terápiás válaszhoz.

Az IRd-terápia törzskönyvezéséhez vezető Tourmaline-MMl klinikai vizsgálat kettős vak-, placebokontrollált, III. fázisú klinikai vizsgálat volt, összesen 722 beteg bevonásával. Ennek során az ixazomibkezelésben is részesülő betegek progressziómentes túlélése szignifikánsan hosszabbnak adódott a placebo + Rd karhoz képest (20,6 hónap vs. 14,7 hónap, 14,7 hónap medián követési idő mellett) [2]. A tanulmány alcsoportelemzése elsősorban arra hívta fel a figyelmet, hogy proteaszómagátló folyamatos alkalmazása képes lehet felülírni a nagy rizikójú citogenetikai eltérések kedvezőtlen prognosztikai hatását. Az már régebb óta ismert, hogy a lenalidomid bázisú folyamatos kezelés különösen kedvező lehet hyperdiploid genetikai háttér (triszómiák) mellett [8]. Hosszú távú túlélőink között a diagnóziskor nem azonosítottunk nagy genetikai rizikójú beteget, ám feltúnő volt, hogy a nem hyperdiploidnak megfelelő, IgH-t érintő transzlokációt hordozó betegek felülreprezentáltak a csoportban. Saját vizsgálatunk és a Tourmaline-vizsgálat megfigyelése között némi analógia vonható: a folyamatos triplet terápia képes lehet eredményesen megnövelni e gyakran kedvezőtlenebbnek gondolt betegcsoport progressziómentességét.

Terpos és mtsai 152 visszaeső, refrakter myeloma multiplexes beteg adatait felhasználó retrospektív, „realworld " tanulmányt közöltek a brit, a cseh és a görög "Named Patient Program" adatainak feldolgozásával [9]. A medián progressziómentes túlélés 27,6 hónap 
volt 9,1 hónap medián követési idő után. A korai közlés adatai ma már meghaladottnak tekinthetők.

Cohen és mtsai 7 izraeli centrum 78, ixazomib alapú kezelésben részesült, relabált és/vagy refrakter myeloma multiplexes beteg adatait elemezték [10]. Az általuk vizsgált betegcsoport a betegek jellemzőiben igen hasonló saját adatainkhoz, a betegség jellemzőiben azonban lényeges különbségek adódtak: betegeinknek mindössze a 27,5\%-a kapta az IRd-kezelést másodvonalban (vs. 64\%), illetve mind a nagy rizikójú citogenetikai eltérések $(8,75 \%$ vs. $32 \%)$, mind a kezelés abbahagyását indokló toxicitás gyakorisága alacsonyabb volt esetünkben ( $0 \%$ vs. $11 \%)$. Az izreali szerzők medián 22 hónap követési idő után igen impresszív, 24 hónapos medián progressziómentességet dokumentáltak. Az általunk talált rövidebb, 10,6 hónapos medián progressziómentes túlélés magyarázatául betegeink nagyobb mértékű előkezeltsége szolgálhat.

Minarik és mtsai tanulmányukban 127, IRd-vel kezelt, visszaeső vagy terápiarefrakter beteg anyagát hasonlították össze paramétereikben illesztett 217, Rd-vel kezelt betegével [5]. A triplet kezelésben részesülő betegcsoport medián progressziómentes túlélése 17,5 hónap volt, míg Rd esetén 11,5 hónap progressziómentességet dokumentáltak, megerősítve a triplet jobb hatékonyságát. Adataikból kiemelendő, hogy extramedullaris betegségre a triplet kezelés érdemi hatást nem gyakorolt (medián progressziómentes túlélés 6,5 hónap). Extramedullaris plasmocytomás beteg saját, hosszú távon túléló betegcsoportunkban sem volt. Vizsgálatuk korlátjaként a következők említendők: az IRd-vel kezelt betegek medián életkora 2 évvel alacsonyabb volt, nagyobb arányban estek át ASCT-n, és magasabb kezdő dózisú lenalidomidkezelésben részesültek $(25 \mathrm{mg})$.

A japán myeloma munkacsoport 122, IRd-kezelésen átesett betegrôl számolt be [11]. Az eltérő gyógyszermetabolizmusuk miatt gyakran különbözően válaszoló ázsiai betegcsoport eredményei is nagyon hasonlóak voltak, a megelőző medián 4 terápiás vonal ellenére a progressziómentes túlélés ebben a tanulmányban - a sajátunkhoz nagyon hasonló - 11,9 hónapnak bizonyult. Érdekes módon az IgG-M-proteint jobb válasz elóhírnökének találták, mi hasonló különbséget adatainkban még trend szintjén sem láttunk.

Az UVEA-IXA „early access ” program elemzése tovább igazolta az ixazomib alapú ambuláns orális terápia biztonságosságát és hatékonyságát: összesen 302 relabált beteg részesült e tanulmány részeként IRd-kezelésben [12]. 279 beteg adatai alapján az ORR 60\%, a medián progressziómentes túlélés pedig 15,6 hónap volt 24,9 hónap medián követési idő elteltével; ezek saját aggregált eredményeinknél némileg jobb értékek.

Jelen tanulmányunkban 7 hazai centrum 80, relabált, refrakter myeloma multiplexes betegének IRd-kezeléssel elért eredményeit elemeztük, kiemelve a kezelés során két éven túl progressziómentesnek bizonyult alcsoportot. A nemzetközi adatoknál ugyan kisebb, de homogé- nebb betegcsoportról van szó, melynek fontos tulajdonsága, hogy az ixazomib-lenalidomid-dexametazon kezelésről szóló nemzetközi cikkek által vizsgált populációkhoz képest jóval előkezeltebb betegekből áll, ami oka lehet a kedvezőtlenebb aggregált progressziómentes túlélési eredménynek. A kezelés megkezdése előtti tumortömeg (ISS-pont) szignifikánsan nem befolyásolta ugyan az eredményt, de az ISS szerinti 3 pont esetén a medián progressziómentes túlélés alig volt több egy évnél. Annak a megfigyelésnek, hogy azonosított citogenetikai jellemzővel nem bíró betegség miért viselkedhet kedvezőtlenebbül, magyarázata lehet, hogy agresszívabbnak gondolt betegség esetén a kezelőorvos a mielóbbi kezelést gondolta szükségesnek, és nem végzett kezelést megelőző csontvelö-aspirációt és kért ebből genetikai vizsgálatot. Lehetséges másik magyarázat a fibroticus csontvelő, mely gyakran kedvezótlenül reagál a lenalidomid bázisú kezelésekre. A kis elemszám miatt ennek analízise tanulmányunkban nem volt lehetséges. Az IgH-transzlokációt hordozó, hosszú távú túlélők görbéjén észlelt plató megerősíti azt az irodalmi adatot, mely szerint a folyamatos triplet kezelés képes megnövelni az alapvetően rosszabb prognózisúnak ítélt betegcsoport túlélését.

Hosszú távú túlélőink analízise alapján megállapíthatjuk, hogy az ixazomib-lenalidomid-dexametazon kombináció jól tolerálható per os kezelés, mely a betegek mintegy hatodánál igen hosszú progressziómentes túlélést tesz lehetővé, az IgH-transzlokációval rendelkező betegek számára is kedvezően hosszú progressziómentes periódus lehetőségének esélyével. A zajló COVID-19járvány mellett egy ilyen tisztán orális, kevés orvos-beteg találkozást igénylő triplet kezelés különösen felértékelődik.

Anyagi támogatás: A közlemény megírása és a kapcsolódó kutatómunka anyagi támogatásban nem részesült.

Szerzői munkamegosztás: Az adatok feldolgozását és a cikk írását $H$. A. végezte, $M$. G. útmutatása révén. A felsorolt szerző́k közül valamennyi hozzájárult cikkünk megírásához az általuk kezelt betegek adatainak megosztásával. A végleges verzió kialakításához valamennyi szerző észrevételeit is felhasználtuk. A cikk végleges változatát valamennyi szerző elolvasta és jóváhagyta.

Érdekeltségek: A szerzőknek nincsenek érdekeltségeik.

\section{Irodalom}

[1] Kazandjian D. Multiple myeloma epidemiology and survival: a unique malignancy. Semin Oncol. 2016; 43: 676-681.

[2] Moreau P, Masszi T, Grzasko N, et al. Oral ixazomib, lenalidomide, and dexamethasone for multiple myeloma. N Engl J Med. 2016; 374: 1621-1634.

[3] Varga G, Nagy Zs, Demeter J, et al. Real world efficacy and safety results of ixazomib, lenalidomide and dexamethasone combination in relapsed/refractory multiple myeloma. Data collected 
from the Hungarian Ixazomib Named Patient Program. Pathol Oncol Res. 2019; 25: 1615-1620.

[4] Kumar S, Paiva B, Anderson KC, et al. International Myeloma Working Group consensus criteria for response and minimal residual disease assessment in multiple myeloma. Lancet Oncol. 2016; 17: e328-e346.

[5] Minarik J, Pika T, Radocha J, et al. Survival benefit of ixazomib, lenalidomide and dexamethasone (IRD) over lenalidomide and dexamethasone $(\mathrm{Rd})$ in relapsed and refractory multiple myeloma patients in routine clinical practice. BMC Cancer 2021; 21: 73.

[6] Saxe D, Seo EJ, Bergeron MB, et al. Recent advances in cytogenetic characterization of multiple myeloma. Int J Lab Hematol. 2019; 41: 5-14

[7] Sonneveld P, Avet-Loiseau H, Lonial S, et al. Treatment of multiple myeloma with high-risk cytogenetics: a consensus of the International Myeloma Working Group. Blood 2016; 127: 2955-2962.

[8] Vu T, Gonsalves W, Kumar S, et al. Characteristics of exceptional responders to lenalidomide-based therapy in multiple myeloma. Blood Cancer J. 2015; 5: e363.

[9] Terpos E, Maouche N, Minarik J, et al. "Real world" data on the efficacy and safety of ixazomib in combination with lenalidomide and dexamethasone in relapsed/refractory multiple myeloma: a combined study from the Greek, Czech and UK databases. Blood 2017; 130(Suppl 1): 3087.

[10] Cohen YC, Magen H, Lavi N, et al. Ixazomib-based regimens for relapsed/refractory multiple myeloma: are real-world data compatible with clinical trial outcomes? A multi-site Israeli registry study. Ann Hematol. 2020; 99: 1273-1281.

[11] Takakuwa T, Yamamura R, Ohta K, et al. Outcomes of ixazomib/lenalidomide/dexamethasone for multiple myeloma: a multicenter retrospective analysis. Eur J Haematol. 2021; 106: $555-562$

[12] Ludwig H, Terpos E, Mateos M, et al. Effectiveness and safety of ixazomib-based therapy in relapsed/refractory multiple myeloma (RRMM) patients (Pts) treated outside the clinical trial setting via an early access program (EAP) in Europe. Second interim analysis of the 'Use Via Early Access to Ixazomib' (UVEA-IXA) Study. Blood 2020; 136(Suppl 1): 42-44

(Varga Gergely dr., Budapest, Szentkirályi u. 46., 1088 e-mail: vargager@gmail.com)

\section{"GYÁSZHÍR”}

Szomorú szívvel, az Úr (Szerk.) akaratában meg (nem) nyugodva vettük tudomásul, hogy a COVID-19-járvány következtében a FOLYÓIRAT-REFERÁTUMOK rovat 2020-ban csendesen eltávozott az Orvosi Hetilapból. A rovat több mint ötven éven át magas szinten szolgálta a hazai orvosképzést.

Gyászolják szülei (akik irták) és barátai (akik olvasták).

Béke poraira!

Pár Alajos dr.

A Szerkesztőség szintén szomorú szívvel tudatja, hogy nemcsak a FOLYÓIRAT-REFERÁTUMOK rovat szünt meg, hanem a KVÍZ is ebben a számban jelenik meg utoljára, mivel ez iránt is csökkent az érdeklődés az utóbbi időben. Mindkét rovat eddig nagy szolgálatokat tett a magyar orvostovábbképzésnek, ugyanakkor a magyar orvosok mai angol nyelvtudása már alkalmas az idegen nyelvü közlemények tanulmányozására, jóllehet a referálók bölcs elemzése hiányozni fog. A tanulmányozandó cikkek kiválasztásában segítséget nyújthat a magyar nyelvű közleményeink végén található, átlagban 50 citátum.

Ugyanakkor az utóbbi másfél évben a váratlan koronavírus-járvány elemi erövel tört utat és követelt helyet magának az Orvosi Hetilap hasábjain is. A COVID-19-PANDÉMIA ORVOSSZAKMAI KÉRDÉSEI című rovatunkban számról számra kitűnő eredeti dolgozatok és összefoglaló tanulmányok olvashatók, amelyek nagyban hozzájárultak lapunk eddig is magas olvasottságához. Mivel soron kívül közöljük a Szerkesztőség által elfogadott, a vírusjárvánnyal kapcsolatos munkákat, ezek gyorsan bekerülnek a nemzetközi vérkeringésbe is, emelve a magyar szerzők munkáinak megbecsülését és cikkeink idézettségét.

Most, hogy a hangsúlyok átrendeződése miatt kénytelenek vagyunk megválni két rovatunktól, őszinte hálával tartozunk mindazoknak, akik e rovatokat gondozták, és hosszú éveken át életben tartották.

A Szerkesztőség

A cikk a Creative Commons Attribution 4.0 International License (https://creativecommons.org/licenses/by/4.0/) feltételei szerint publikált Open Access közlemény, melynek szellemében a cikk bármilyen médiumban szabadon felhasználható, megosztható és újraközölhetö, feltéve, hogy az eredeti szerző és a közlés helye, illetve a CC License linkje és az esetlegesen végrehajtott módositások feltüntetésre kerülnek. (SID_1) 